Document downloaded from:

http://hdl.handle.net/10251/67747

This paper must be cited as:

Peró, M.; Soriano Jiménez, PP.; Capilla Lladró, R.; Guàrdia I Olmos, J.; Hervás, A. (2015). Questionnaire for the assessment of factors related to university degree choice in Spanish public system: A psychometric study. Computers in Human Behavior. 47:128-138. doi:10.1016/j.chb.2014.09.003.

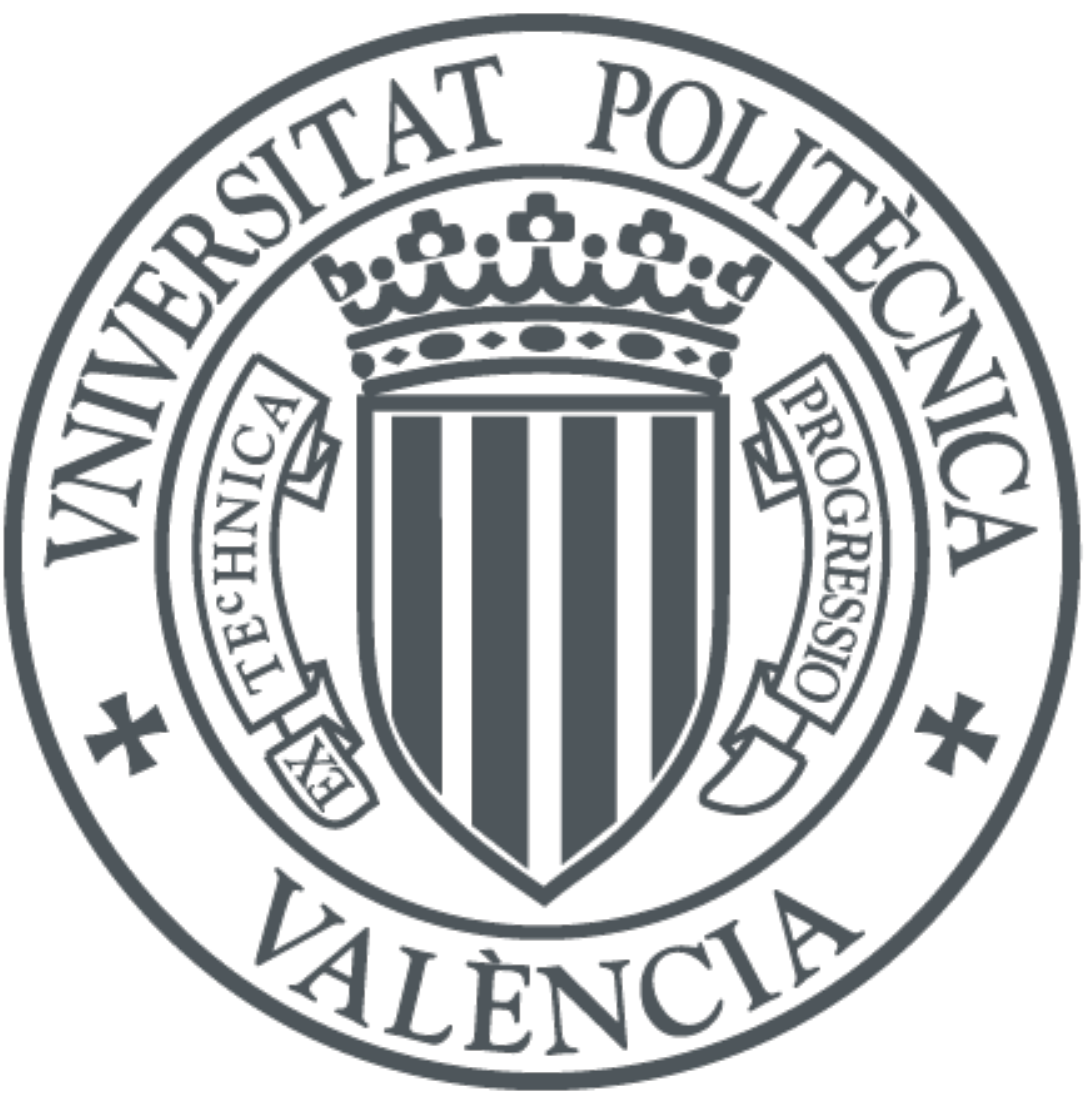

The final publication is available at

http://dx.doi.org/10.1016/j.chb.2014.09.003

Copyright Elsevier

Additional Information 


\title{
Questionnaire for the assessment of factors related to university degree choice in Spanish public system: a psychometric study
}

\begin{abstract}
Universities are interested in attracting students, but they do not usually have data relating to students' intentions. Furthermore, both general and subjective factors are taken into account by students when choosing a degree and a university. This paper presents a psychometric study of a questionnaire which aims to assess variables relating the aspects involved in the selection process and accessing the Spanish university system. This questionnaire considers six factors: Consideration of the University; Perceived Usefulness; Social Impact; Vocational Aspects; Influence of Surroundings and Geographic Location. The item analysis (discrimination index) reduced the questionnaire to 25 items, and the reliability and validity of this final questionnaire was analyzed using a sample of 1532 students from eight Spanish universities. The results showed that the reliability as internal consistency of the six factors was high; the construct validity showed a structure of six first order factors clustered in two second order factors and finally, there was high discriminant validity between groups defined by variables such as gender or academic area. Applying predictive analytics to the results of this questionnaire will then enable specific recruiting policies to be applied, which target the type of students that universities are looking for, while reducing costs.
\end{abstract}

\section{Highlights}

- $\quad$ The Spanish public university access system is described.

- A questionnaire is proposed for the assessment of factors associated with the choice of degrees.

- $\quad$ Psychometric study: reliability and construct validity.

- A tool is presented that can be used to design recruitment policies for universities.

\section{General Terms}

Management, Human Factors, Psychometric study.

\section{Keywords}

Confirmatory Factor Analysis, University Access, Higher Education Management, Learning Analytics, Analytic analysis.

\section{INTRODUCTION}

Information technology and communication, or ICT, are now present in almost every aspect of campus life, reaching far beyond what we might call administrative management to academic management and, through specific tools, to teaching and learning processes, research and research management, etc. This enables a large quantity of information to be obtained that can then be reused to improve the system.

"Learning Analytics (LA) is the measurement, collection, analysis and reporting of data about learners and their contexts, for purposes of understanding and optimizing learning and the environments in which it occurs. Academic analytics, (AA), is the application of business intelligence in education and emphasizes analytics at institutional, regional, and international levels” (Long \& George, 2011). AA datasets combine statistical techniques, process modeling, and predictive models to analyze the performance of the organization and propose improvement systems. An interesting contribution from the point of view of Data Mining can be found in Romero \& Ventura, 2010, and in Mignaei-Bigdoli et al, 2003. 
In this respect, this study addresses one of the fundamental problems faced by universities: the recruitment of talent. The best students are desired by the best universities and even by universities which are not rated as highly.

This problem is a result of two determining factors: firstly, each of the countries' specific laws regulating access to the university; and secondly, the factors which lead students to select a particular university degree.

The factors that lead students or their families to choose a certain university and higher education degree have been studied by several authors, and especially by universities themselves (Guerra \& Rueda, 2005). Knowledge of these factors can obviously lead to a competitive advantage when designing advertising campaigns and activities targeting potential clients. Using this kind of language, which relates more to commercial marketing than academic discourse, was frowned upon by some sectors of the academic community just a few years ago, but strictly marketing-based student attraction strategies would not have a promising future (Maringe, 2006; Perna \& Titus, 2004; Price, Matzdorf, Smith \& Agahi, 2003). However, the current competitive environment has led it to be assumed that such techniques and procedures should and are used to attract talent. With proper recruitment policies and guidance the cost of attracting students can be lowered while improving results. According to the European Access Network (EAN) (www.ean-edu.org) recruitment costs per student admitted varies from $€ 3$, to $€ 7$.

The recruitment systems depend on several factors, the first of which include the procedure for accessing the university system, and the financing of the system itself. In Spain, there are 81 universities, of which 32 are private and 49 are public. The public universities admitted a total of 245,181 students in 2012, representing 78.4\% of all new students in Spanish universities. These students were enrolled in one of the 4358 degree programs offered by public universities.

Access to private universities which freely set their prices, is based on the submission of an application and acceptance for admission by the private college based on its own criteria. On the other hand, the public university system is funded by the state, and students only pay from $10 \%$ to $15 \%$ of the actual estimated cost of their studies. The majority of students in Spain attend public which have the highest number of degrees. These public universities offer a certain number of places for each degree course. In order to be admitted, students are required to take a university entrance exam known as, PAU (Prueba de Acceso a la Universidad) and may then request enrollment in a given maximum number of degree courses in order of preference. Based on the marks obtained on the PAU, students are then either assigned a place in a university degree course, or they fail to obtain a place. Consequently students use strategies to try to optimize their chances of being admitted into the desired degree course, since in the end they may not be accepted into the degree course they prefer or even be given a place in the University.

In other European countries, the students are required to pass an entrance exam for the specific degree course requested (Parry et al., 2006). In the case of China, there is an entrance test called Gaokao, which is similar to the Spanish exam but is much more restrictive, and in Australia, there are specific tests, such as the GAMSAT for Medical Schools, (Dawson et al, 2011). In the USA, recruitment systems are based on a system where applications are submitted and are either accepted or rejected, but in this case the financial resources of prospective students and scholarship and grant policies play a decisive role. This process has been studied from different points of view. The Gale-Shapley algorithm (1962) for the assignment of students to universities is a basic reference (Gale \& Shapley, 1962). Murphy and McGarrity (1978) concluded that the consideration of the quality of the system and confidence in the institution was the key factor for students when making a choice. The results have been effectively tested in the case of engineering (Yurtseven, 2002), or that of the recruitment of women and ethnic minorities, (Ford, 2008; Leppel, Williams \& Waldauer, 2001; Turner \& Thompson, 1993). As discussed earlier, other authors analyze the relationship between the attraction and retention of these students (León, 2011; Tinto, 2006), while others (Misran et al., 2012) consider the influence of the socio-economic status of the students enrolled on their decision regarding which college to select, and finally, others (Huffman, Whetten, \& Huffman, 2013) study the relationship between the factors of gender and academic outcomes and use of technologies

In Spain the first approach to identifying indicators of quality in the choice of degree and university studies appears in Guerra and Rueda (2005), and Capilla (2009), studying the evolution of these indicators depending on the demand especially in degrees with high / low demand It is considered that the demand for a degree or university is directly related to the students' and their environment's subjective perception of that degree (Baker \& Brown, 2007; Maringe, 2006). Furthermore, students' perceptions of such indicators do not seem to have been appropriately verified. In many cases utility is attributed to degrees that are not actually in great demand, and vice versa. Moreover, it has been found that although 
they appear repeatedly in studies and forums, personal factors and the social influence affecting decisionmaking, have not been adequately measured (Barnes \& Mattson, 2009; Bowden \& Wood, 2011; Guerra \& Rueda, 2005; Lubben, Davidowitz, Buffler, Allie, \& Scott, 2010 ). Also significant are the strategic actions taken by universities aimed at recruiting students either directly or indirectly through strategic plans in $\mathrm{R}+\mathrm{D}+\mathrm{i}$, comprehensive management or a relationship with the environment (Corominas \& Sacristan, 2011; León, 2011) or perhaps by using social networks, because those who are best connected do better in their life (Benson, Morgan, \& Filippaios, 2014; Cheung, Chiu, \& Lee, 2011).

The information regarding the preferences or criteria that lead students to select a certain university degree, is, in fact data which give universities a competitive and strategic advantage when designing their recruitment programs.

Universities have the need to implement analytical procedures in order to analyze factors such as performance in terms of means of access, dropping out, dependence on the access mark, etc. Furthermore, predictive models should be developed to identify the students who are most preferable, in order to be more effective and achieve greater performance. In the case of the European Higher Education Area, EHEA, systems for validation, verification and accreditation of degrees have been established. This is an age where accountability and liability of public Institutions is demanded, and the AA is a suitable instrument for achieving this purpose.

Having first analyzed and compared the Spanish public university access system to the access systems in place in other universities, and then explained the relationship between this problem and AA, section 2 of this paper describes the aims of our study, section 3 focuses on the method followed for obtaining the questionnaire, section 4 presents the results and confirmatory statistical analysis, and finally, section 5 presents the conclusions of our study.

\section{OBJECTIVES}

Our objective is to present a psychometric study of a questionnaire that has been developed for the study of variables relating to social and personal aspects involved in the university selection process and accessing the Spanish public university system. As shown by Guàrdia et al. (2012, 2013), or Hervás, Guàrdia, Peró, Capilla and Soriano (2013) this process involves factors associated with mechanisms for pre-registration in Spain, such as cut-off marks, degrees offered, the number of places available for each degree and even the gender of students, since the first choices made are not independent from this variable.

Therefore, in addition to these fundamental variables that can be defined as context variables, there are social and personal factors involved in choosing a university degree which are systematically assessed by means of the questionnaire used in this study.

\section{METHOD 3.1 Participants}

From the academic year 2009-2010 to the academic year 2012-2013, various samples of different populations of first year students attending certain Spanish public universities were obtained to serve as a sample of the Spanish Public University System:4 large generalist universities, 2 specialized universities, and 2 medium sized universities (see Table 1). This sample was used to establish the different questionnaire analysis phases. The selection of the 8 universities was random and in each university a non-probabilistic sampling was done in which the probability of selection was not equal for all population's members. For this purpose, questionnaires were first sent to the different faculties and colleges via the internet and various requests were made to first year students to complete it. After a few weeks the questionnaire was closed and the corresponding database per University was then made. The samples included a total of 1532 first year students, all of which accessed the University from Baccalaureate programs, since the questionnaires of those students accessing the university in other ways were not included in the sample. The resulting descriptive data are given in Table 1:

Table 1. Final sample descriptive values

\begin{tabular}{ll}
\hline VARIABLE & DESCRIPTIVE \\
\hline Gender & $61 \%$ Female and 39\% Men \\
\hline Age & $M=18.12 ; D T=1.77 ;$ Ranging from17 to 25. \\
\hline Year of Access & $11 \%$ in 2009-2010 \\
\hline
\end{tabular}




\begin{tabular}{ll}
\hline & 28\% in the year 2010-2011 \\
& $43 \%$ in 2011-2012 \\
& 18\% in the year 2012-2013 * \\
& * Sample not completed for this course \\
\hline Academic area & Educational Sciences: 12\% \\
& Experimental Sciences and Mathematics: 9\% \\
& Health Sciences: 22\% \\
& Social Sciences: 23\% \\
& Humanities and Fine Arts: 12\% \\
& Engineering and Architecture: 22\% \\
\hline University of Origin & Universitat Politécnica de Valencia: 30\% \\
& Universitat de Barcelona: 24\% \\
& Universidad Pablo Olavide: 5\% \\
& Universidad de Salamanca: 8\% \\
& Universidad de Granada: 5\% \\
& Universidad de Oviedo: 11\% \\
& Universitat Politècnica de Catalunya: $8 \%$ \\
& Universidad Complutense de Madrid: $9 \%$ \\
\hline
\end{tabular}

\subsection{Questionnaire}

The works of Capilla (2009) and Guerra (2005) as well as those carried out by some universities, such as the University of Barcelona, the UPO Barometer Pablo Olavide University (Llera, 2010) or the study led by Ariño, Hernández, Llopis, Navarro and Tejerina (2008) at the University of Valencia, among others, are clear antecedents of the questionnaire used in this study. From the aforementioned studies, an initial proposal was made of items to be included in a Likert scale (1-6 points, defining a seventh option for "Do not know" or "No answer" in order to correctly define missing values) to operationally define the following factors or latent variables a) Consideration of the University, b) Perceived Usefulness c) Social Consideration d) Vocational Aspects e) Influence of surrounding and f) Geographical Location. These six factors were considered to be taken in account by students when selecting a university degree, in addition to other personal factors and data relating to institutional variables: a) The previous year's degree access mark b) The number of places available for the degree; c) the number of registered definitive first choices, and d) the first choice requests for a specific degree.

A first version of the questionnaire was then developed. The questionnaire was made up of 59 different items grouped under each of the six factors before described: 12 items relating to consideration of the University, 10 to Perceived usefulness, 9 to Social consideration, 14 to Vocational aspects, 9 to Influence of surroundings and 5 to Geographic location. See Table 2.

In order to analyze the content validity of the questionnaire, this first version of the questionnaire was sent to eight experts on the system for accessing different Spanish public universities. Each of the experts was requested to assign each item to one of six factors proposed and to analyze the wording and understanding of each item. For this purpose, they were provided with a simple response system to allocate each item to one of the six factors and rate the wording and comprehension of each item on a scale of 1 (least difficulty) to 10 points (maximum difficulty). Data on the 59 items showed high agreement on the allocation of factors (Kappa index $=.93$ ) and low comprehension difficulties given that the item assessed as being most difficult showed a $\mathrm{M}=4.21$ and a $\mathrm{SD}=0.81$ which is a relatively low level of comprehension of the item considering the range of the proposed assessment.

From this first test scale, items for which there was no agreement with respect to allocation to factors and those with an average of over 4 in the evaluation of difficulty in understanding were eliminated. The resulting second scale included 49 test items distributed equally among the six factors, except for the Geographic factor, for which there was in fact a lower number of items in the first version of the questionnaire (Table 2).

The second scale was then applied to a pilot sample made up of first year students that met the criteria described in the section on participants. This sample consisted of 252 students (21\% from the University Pablo de Olavide, 39\% from the Universitat de Barcelona and 40\% from the Universitat Politècnica de Valencia). These 49 items were measured on a 6 point Likert scale, from 1: strongly disagree with the statement to 6: totally agree with the statement, with a 7 point response for “don't know or no answer”. 
In order to analyze the responses made by these 252 students we performed an item analysis obtaining the discrimination index for each item so as to evaluate the characteristics of the item. We also obtained the alpha coefficient in order to study the reliability as internal consistency of the questionnaire. In table 3 we show the coefficient alpha for the six factors, and the reliability as internal consistency could be considered excellent in all the factors (value of coefficient alpha superior to .85) (Muñiz, 2005).Those items whose discrimination coefficient values were less than 0.40 were eliminated from the test scale; leading to an increase in the reliability of the factor to which they were assigned.

It is important to highlight that there was a clear tendency to use the seventh category for items which should not generate complex or nonexistent responses, since the items relate to basic details for a student (for example, when assessing their level of satisfaction with the information received from the universities to aid in access to the university). In order to reduce this lack of response to the items, and bearing in mind that score of 7 was equivalent to "no response" for the item, we made the decision to eliminate this option and maintain a Likert scale of 1-7 points to encourage greater discriminability in the final questionnaire. Therefore, in view of all the above values and criteria, the final scale consisted of a total of 25 items assigned according to Table 2 to each of the six factors considered, and can be found in the appendix to this work. Again, it is important to point out that of the six factors considered; the Geographic location factor is the one with the least number of items.

Two questions in the pilot questionnaire for which there were very polarized responses to extreme categories were removed from the 25 items scale but were maintained in the global questionnaire as dichotomous questions (yes/no answer). These questions were:

- $\quad$ Did you know how many places were being offered?

- In view of my access mark, I could choose the degree I preferred.

Table 2. Distribution of items by factor in the three test scale

\begin{tabular}{|c|c|c|c|c|}
\hline FACTOR & LATENT FACTOR & $\begin{array}{l}\text { Number of } \\
\text { items in the } \\
\text { first test }\end{array}$ & $\begin{array}{l}\text { Number of } \\
\text { items in the } \\
\text { second test }\end{array}$ & $\begin{array}{l}\text { Number of items } \\
\text { in the final test. }\end{array}$ \\
\hline \multirow{3}{*}{$\begin{array}{c}\text { Social } \\
\text { Factors }\end{array}$} & Consideration of the University & 12 & 10 & 5 \\
\hline & Perceived usefulness & 10 & 9 & 3 \\
\hline & Social consideration & 9 & 8 & 3 \\
\hline \multirow{3}{*}{$\begin{array}{l}\text { Individual } \\
\text { Factors }\end{array}$} & Vocational aspects & 14 & 10 & 4 \\
\hline & Influence of surroundings & 9 & 8 & 8 \\
\hline & Geographic location & 5 & 4 & 2 \\
\hline
\end{tabular}

Table 3. Values of reliability ( $\alpha$ of Cronbach) for test scale.

\begin{tabular}{llc}
\hline FACTOR & LATENT FACTOR & Reliability \\
\hline \multirow{3}{*}{ Social Factors } & Consideration of the University & .88 \\
& Perceived usefulness & .82 \\
& Social consideration & .91 \\
\hline \multirow{3}{*}{ Individual Factors } & Vocational aspects & .88 \\
& Influence of surroundings & .91 \\
& Geographic location & .94 \\
\hline
\end{tabular}

In figure 1 we show the path diagram of the measurement model proposed. As can be seen, a second order factor analysis is proposed, where the items 1, 3, 16, 17 and 18 load in Consideration of University, the items 21, 24 and 25 load in Perceived usefulness, the items 19, 20 and 23 load in Social consideration, the items 12, 14, 15 and 22 load in Vocational aspects, the items 4, 5, 7, 8, 9, 10, 11 and 13 load in Influence of surroundings and the items 2 and 6 load in Geographic location. The second order factor Social Factors consisted of Consideration of university, perceived usefulness and social consideration, and the second order factor Individual Factors included vocational aspects, influence of surroundings and geographic location. A correlation between these two second order factors is proposed as shown in figure 1. 


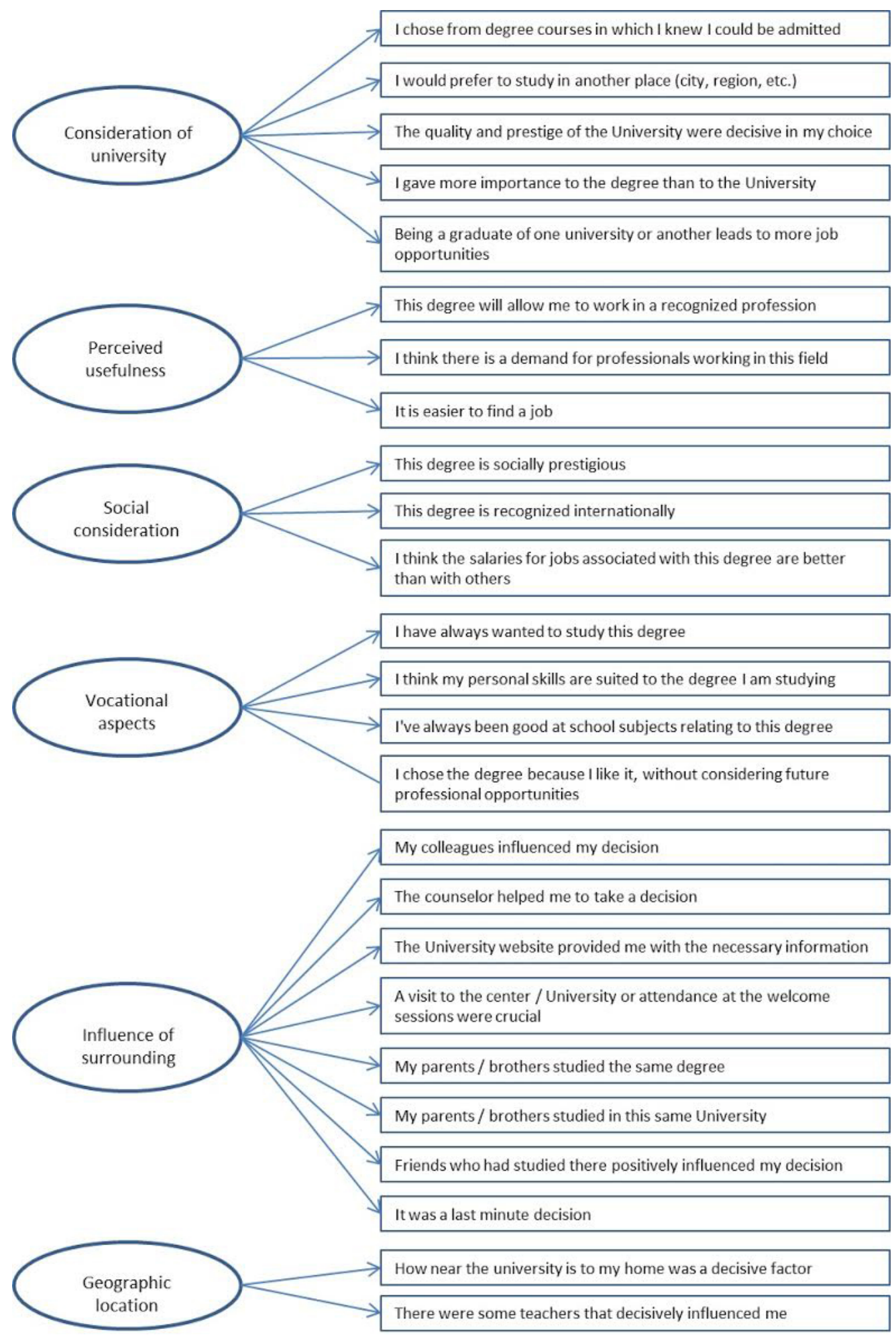

Figure 1. Path diagram of the measurement model of the questionnaire for the assessment of factors related to university degree choice.

\subsection{Procedure}

An online questionnaire was found to be the best option for distributing the questionnaires among universities and unifying the results recorded. LimeSurvey was the tool chosen for this purpose since it is a free and open survey application based on a scalable MySQL database which the team is highly familiar with and has tested. 
A different questionnaire was developed for every university, with a first question requiring students to select the faculty or school they are in, and a second question requiring them to select their degree from among the degrees offered by this faculty or school. In order to make the survey as short as possible, a set of degree lists were included, but only the one related to the faculty or school selected was made visible to the students.

LimeSurvey also provides other information about the answers recorded, such as the time spent to complete the questionnaire, the date and time, and the computer IP, etc. The IP data was interesting since it enabled us to know if the connection was made from the faculty/school or from home. It was found that about $90 \%$ of the connections were made from home.

This final version was sent electronically via an "ad-hoc" application of the Universitat Politécnica de Valencia, which was sent to the eight universities in the public system. The questionnaire was also administered on paper in some cases. Of the total questionnaires sent, about 56\% completed questionnaires were received, of which 1532 met the inclusion criteria described in the section on participants, being first year students attending certain Spanish public universities. This process was carried out from December 2009 to March 2013 and in all cases, none of the questionnaires using the final scale were completed by students who appeared in previous test scales.

\section{RESULTS}

\subsection{Analysis of Reliability and Construct Validity.}

A psychometric analysis of the data collected was carried out by first estimating reliability and construct validity through a second order confirmatory factor analysis using MPlus software. The technique of parameter estimation (factor loading matrix $-\Lambda_{x^{-}}$and correlation between the factors) was maximum likelihood (ML), with a full estimation based on the Spearman-Brown matrix of correlations due to the ordinal nature of the reference scale.

Table 4 shows the fit indices for the adjusted measurement model, a quick review of the values shows a reasonably good fit except for the $\chi^{2}$ statistic of fit, which is statistically significant. However, the values of the ratio of $\chi^{2}$ 's estimated value and their degrees of freedom are excellent (inferior to 3 ). To interpret these indices the following criteria were used: $\chi^{2} / \mathrm{df}$ ratio $<2$ (excellent); $\chi^{2} / \mathrm{df}<3$ (good); $\chi^{2} / \mathrm{df}<5$ (acceptable); good fit for GFI, AGFI, BBNFI, BBNNFI and CFI $\geq .90$; RMSE $\leq .05$; and SRMSE $\leq .06$ (Hu \& Bentler, 1999), in fact, according to Browne and Cudeck (1992) and Hu and Bentler (1999), RMSE $\leq .08$ and SRMSE $\leq .08$ indicate an acceptable fit.

The values of reliability were obtained for the first and the second order factors following the estimation of Satorra-Bentler of internal consistence reliability (table 4). The factor consideration of the University has good reliability as internal consistency, and the other five factors have adequate internal consistence reliability. In relation to the second order factors, the social factor has good reliability as internal consistency and the individual factor has excellent reliability as internal consistency (Muñiz, 2005).

Table 4. Fit indices for the confirmatory factorial analysis and reliability coefficients $(\mathrm{n}=1532)$

\begin{tabular}{lc}
\hline FIT INDICATOR & Value \\
\hline Goodness of Fit Index (GFI) & .966 \\
Adjusted Goodness of Fit Index (AGFI) & .962 \\
Bentler Bonnet Normed Fit Index (BBNFI) & .958 \\
Bentler Bonnet Non Normed Fit Index (BBNNFI) & .952 \\
Comparative Fit Index (CFI) & .949 \\
Coefficient of Determination ( ${ }^{2}$ ) & .544 \\
Root Mean Standard Errors (RMSE) & .005 \\
Standardized Root Mean Standard Errors (SRMSE) & .002 \\
$\chi^{2}$ with df = 412 & 973.21 \\
Ratio $\chi^{2}$ / df & $(p<.05)$ \\
Akaike Information Criteria AIC & 2.3621 \\
Bayesian Information Criteria & $-1324,11$ \\
\hline \multicolumn{1}{c}{ Reliability values for First Order Latent factors } \\
\hline Consideration of University & $\alpha=.81399 .71$ \\
\hline Perceived usefulness & $\alpha=.791$ \\
Social consideration & $\alpha=.735$ \\
Vocational aspects & $\alpha=.799$ \\
\hline
\end{tabular}




\begin{tabular}{lc}
\hline Influence of surroundings & $\alpha=.732$ \\
Geographic location & $\alpha=.750$ \\
\hline \multicolumn{1}{c}{ Reliability values for Second Order Latent Factors } \\
\hline Social & $\alpha=.812$ \\
Individual & $\alpha=.874$ \\
\hline
\end{tabular}

Figure 2 shows the path diagram with the standardized parameters estimated for the measurement model proposed. All the factorial loads estimated were statistically significant, which is another argument in favor of the proposed model. In general all the factorial loads have a great intensity, eleven of the twenty five factorial loads between the items and the six first order factors were greater than .4, and for the factorial loads relating the six first order factors to the two second order factors, the lowest load was found to be between social factor and perceived usefulness (value: .679). The other five loads had scores upper .7. The correlation between the two second order factors (social and individual factors) was of moderate intensity (.462).

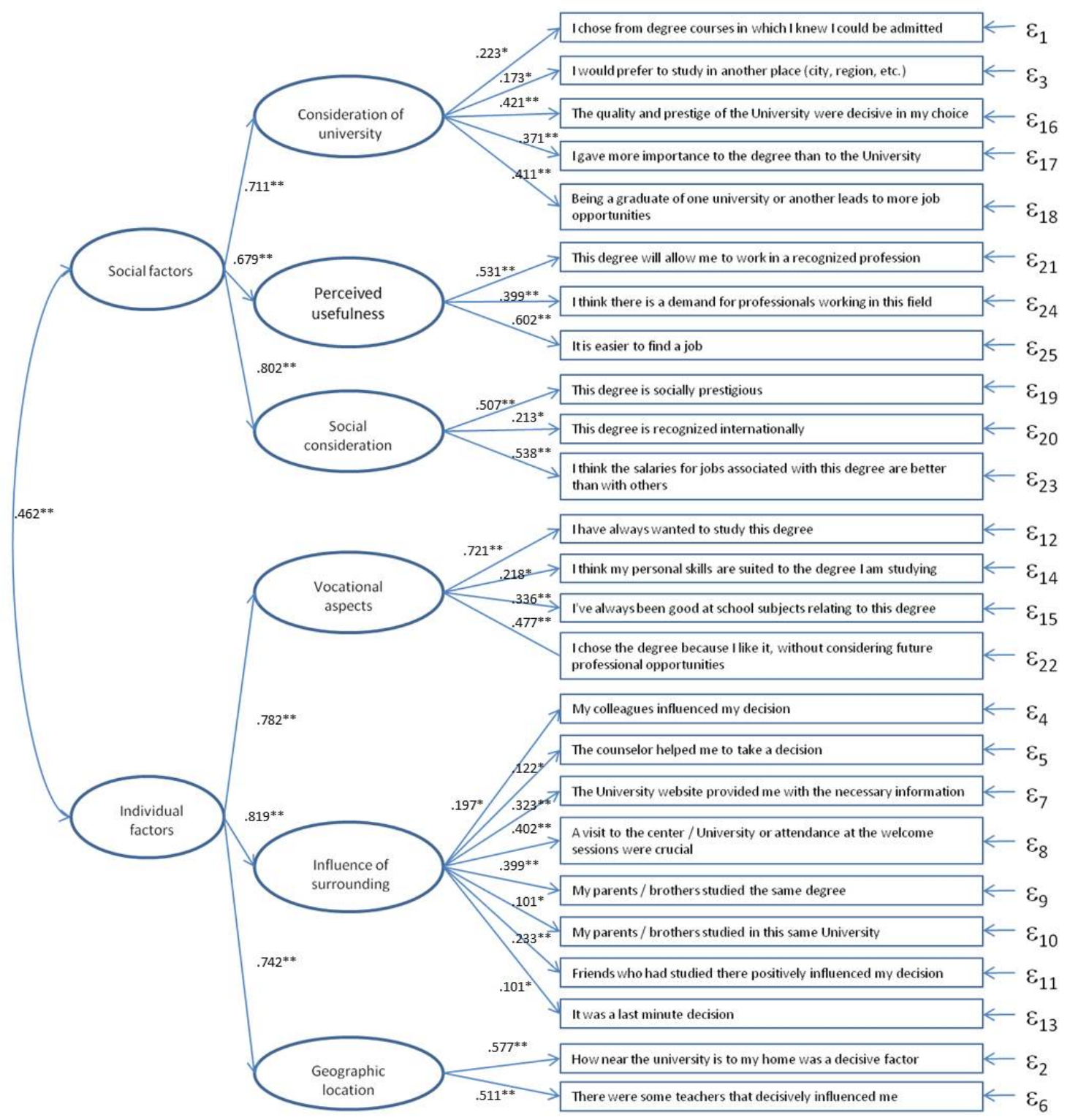

Figure 2. Path diagram of the second order confirmatory factor analysis with the standardized parameters solution $(* \mathrm{p}<.05 ; * * \mathrm{p}<.01)$. 


\subsection{Discriminant Validity}

In order to provide some evidence of discriminant validity we compared the score for each of the six factors depending on the gender of the students and the academic area of origin when they access the University (six values: science education, experimental sciences and mathematics, health sciences, social sciences, humanities and arts and engineering and architecture). For the rest of the variables obtained in the general questionnaire no comparison was made because there was no variation in the response of the students. The score for each factor was obtained by adding the scores of the items assigned to each factor. For the variable gender we made six t-tests of independent samples, and for the academic area of origin we made six one-way ANOVAs of independent samples (Table 5).

Table 5. Comparisons between the means of the latent first order factors by sample groups $(\mathrm{n}=$ 1532).

\begin{tabular}{|c|c|c|c|c|c|c|c|}
\hline Variables & Groups & $\begin{array}{l}\text { Consideration } \\
\text { of the } \\
\text { University }\end{array}$ & $\begin{array}{l}\text { Perceived } \\
\text { usefulness }\end{array}$ & $\begin{array}{l}\text { Social } \\
\text { consideration }\end{array}$ & $\begin{array}{l}\text { Vocational } \\
\text { aspects }\end{array}$ & $\begin{array}{l}\text { Influence of } \\
\text { surroundings }\end{array}$ & $\begin{array}{l}\text { Geographic } \\
\text { location }\end{array}$ \\
\hline \multirow{7}{*}{ Gender } & \multirow{2}{*}{ Men } & $\mathrm{M}=32.12$ & $\mathrm{M}=15.14$ & $\mathrm{M}=16.12$ & $\mathrm{M}=11.12$ & $\mathrm{M}=31.12$ & $\mathrm{M}=9.11$ \\
\hline & & $\mathrm{SD}=2.77$ & $\mathrm{SD}=1.12$ & $\mathrm{SD}=1.20$ & $\mathrm{SD}=1.44$ & $\mathrm{SD}=2.04$ & $\mathrm{SD}=1.12$ \\
\hline & \multirow{2}{*}{ Women } & $\mathrm{M}=36.14$ & $M=12.14$ & $M=14.11$ & $M=14.13$ & $M=30.33$ & $M=9.44$ \\
\hline & & $\mathrm{SD}=2.31$ & $\mathrm{SD}=1.44$ & $\mathrm{SD}=2.11$ & $\mathrm{SD}=1.12$ & $\mathrm{SD}=2.77$ & $\mathrm{SD}=0.91$ \\
\hline & \multirow{3}{*}{ Contrast } & $t=12.77$ & $t=21.77$ & $t=17.71$ & $t=17.02$ & $t=4.09$ & $t=5.77$ \\
\hline & & $p<.001$ & $p<.001$ & $p<.001$ & $p<.001$ & $p=.412$ & $p=.231$ \\
\hline & & $r=.43$ & $r=.51$ & $r=.48$ & $r=.47$ & No Sig. & No Sig. \\
\hline \multirow{14}{*}{$\begin{array}{l}\text { Academic } \\
\text { Area }\end{array}$} & \multirow{4}{*}{$\begin{array}{l}\text { Science } \\
\text { Education } \\
\text { Experimental } \\
\text { Sciences and } \\
\text { Mathematics }\end{array}$} & $\mathrm{M}=30.12$ & $\mathrm{M}=11.11$ & $\mathrm{M}=14.12$ & $\mathrm{M}=14.11$ & $\mathrm{M}=27.12$ & $\mathrm{M}=8.78$ \\
\hline & & $\mathrm{SD}=2.11$ & $\mathrm{SD}=1.43$ & $\mathrm{SD}=2.44$ & $\mathrm{SD}=1.51$ & $\mathrm{SD}=2.04$ & $\mathrm{SD}=1.07$ \\
\hline & & $\mathrm{M}=31.21$ & $\mathrm{M}=10.12$ & $\mathrm{M}=16.88$ & $M=10.13$ & $\mathrm{M}=28.33$ & $\mathrm{M}=9.01$ \\
\hline & & $\mathrm{SD}=2.55$ & $\mathrm{SD}=1.67$ & $\mathrm{SD}=2.54$ & $\mathrm{SD}=1.27$ & $\mathrm{SD}=2.78$ & $\mathrm{SD}=1.44$ \\
\hline & Health & $M=34.27$ & $M=14.12$ & $M=16.27$ & $M=13.70$ & $M=25.32$ & $M=9.44$ \\
\hline & Sciences & $\mathrm{SD}=2.51$ & $\mathrm{SD}=2.01$ & $\mathrm{SD}=2.01$ & $\mathrm{SD}=1.37$ & $\mathrm{SD}=2.91$ & $\mathrm{SD}=1.23$ \\
\hline & Social & $\mathrm{M}=29.12$ & $M=14.11$ & $M=16.21$ & $\mathrm{M}=12.13$ & $M=23.45$ & $\mathrm{M}=9.22$ \\
\hline & Sciences & $\mathrm{SD}=2.14$ & $\mathrm{SD}=1.99$ & $\mathrm{SD}=2.15$ & $\mathrm{SD}=1.34$ & $\mathrm{SD}=3.23$ & $\mathrm{SD}=1.55$ \\
\hline & \multirow{3}{*}{$\begin{array}{l}\text { Humanities } \\
\text { and Arts } \\
\text { Engineering } \\
\text { and } \\
\text { Architecture }\end{array}$} & $M=28.21$ & $M=10.12$ & $M=12.11$ & $M=14.02$ & $M=24.11$ & $M=9.65$ \\
\hline & & $\mathrm{SD}=2.71$ & $\mathrm{SD}=2.12$ & $\mathrm{SD}=2.13$ & $\mathrm{SD}=2.02$ & $\mathrm{SD}=2.82$ & $\mathrm{SD}=1.27$ \\
\hline & & $\begin{array}{l}M=31.66 \\
S D=2.99\end{array}$ & $\begin{array}{l}M=14.23 \\
S D=2.31\end{array}$ & $\begin{array}{l}M=14.33 \\
S D=2.41\end{array}$ & $\begin{array}{l}M=13.97 \\
S D=2.11\end{array}$ & $\begin{array}{c}M=22.97 \\
S D=2.49\end{array}$ & $\begin{array}{l}M=9.77 \\
S D=0.92\end{array}$ \\
\hline & \multirow[t]{3}{*}{ Contrast } & $F=12.15$ & $F=23.11$ & $F=18.12$ & $F=15.73$ & $F=7.72$ & $F=6.11$ \\
\hline & & $p=.038$ & $p=.001$ & $p=.027$ & $p=.031$ & $p=.287$ & $p=.328$ \\
\hline & & $\varepsilon^{2}=.231$ & $\varepsilon^{2}=.487$ & $\varepsilon^{2}=.298$ & $\varepsilon^{2}=.272$ & No Sig. & No Sig. \\
\hline
\end{tabular}

$M=$ Mean, $S D=$ Standard Deviation, $t=$ value of the t-test of independent groups, $p=$ significance value, $r=$ value of effect size for the t-test, $F=$ value of Snedecor test for ANOVA, $\varepsilon^{2}=$ measure of effect size for ANOVA

Based on the above table it can be concluded that the factors are not distributed homogeneously by gender or academic area. Whereas the women tend to score university consideration $(t=12.77, p<.001, r=.43)$, and vocational aspects ( $t=17.02, p<.001, r=.47)$ higher than men, men tend to score perceived usefulness $(t=21.77, p<.001, r=.51)$ and social consideration $(t=17.71, p<.001, r=.48)$ higher than women. There was no statistically significant difference in the case of influence of surroundings or geographic location. Regarding academic area of origin, ANOVA statistical analysis was carried out. All the observed distributions were normally distributed (Shapiro-Wilks Test non-significant in all factors) and the homogeneity condition was successfully analyzed (Levene Test non-significant in all factors). Statistically significant differences were found for the factors and the post-hoc analysis allowed to highlight some important results: consideration of the university which were scored higher by students of Health Sciences $(\mathrm{F}=12.15, \mathrm{p}=.038, \varepsilon 2=.231)$; perceived usefulness, which was scored higher by Engineering students $\left(F=23.11, p=.001, \varepsilon^{2}=.487\right)$; social consideration which was scored higher by Experimental Science students $\left(F=18.12, p=.027, \varepsilon^{2}=.298\right)$; and finally vocational aspects, which were scored higher by students of Educational Sciences $\left(F=15.73, p=.031 ; \varepsilon^{2}=.272\right)$. These results indicate that there is a need to study the above aspects more in-depth, and evidences the usefulness of the questionnaire for this purpose. 


\section{DISCUSSION}

From the results obtained, it can be concluded that the proposed questionnaire allows for the evaluation of factors relating to social and personal aspects involved in the process of choosing a university and degree in the Spanish public university system. Obviously, these are only two of the factors involved in this complex process of student decision making (Guàrdia et al., 2012, 13; Hervás et al., 2013), which should be studied as a whole using structural equation modeling in order to also examine the structural relationship and the different constructs implied.

The content validity of the questionnaire was ensured by the revision and assessment from expert judges; it is important to highlight the high value of the discrimination index for the different items included on the final questionnaire $(>.40)$.

The reliability and construct validity values evidence that this questionnaire is a good assessment instrument, because the internal consistence reliability values are good and even excellent for some factors. Additionally, second order confirmatory factorial analysis proposed for the measurement model of the questionnaire shows a good fit and the factorial loads estimated are all statistically significant, and in some cases with a high value. Particularly interesting are the results obtained in the section on discriminant validity, which show that the various factors considered are not distributed similarly in terms of academic area or gender. Vocational aspects were found to be of more significance to students of Educational or Health Sciences, while, for example, issues relating to utility were of more interest to students pursuing Engineering or Architecture degrees. High values were also shown for Geographic location, but without major differences between areas, this being a factor which was given importance by students regardless of their area of study. In relation to the gender variable, women's' scores were higher for vocational aspects or consideration of the university, while men gave less importance to these factors when deciding on which degree and university to choose.

It is important to point out that gender and academic area of origin might not be the best variables for studying the discriminant validity of the questionnaire. It is possible that statements like: "this degree was my first choice when pre-registering”, "this university was my first choice when pre-registering”, "the cut-off mark has influenced my choice”, "I know what is the student quota for this degree", or "in view of my access mark I could choose the degree I preferred", might be better variables to use to determine whether the questionnaire discriminates between groups. In this study, we have collected this information, but the sample is not big enough for group comparison using these variables. In future studies we suggest to increase the sample size in order to have enough samples for each group, which would allow for an improved study of the discriminant validity aspect.

Therefore it can be concluded that this preliminary assessment tool can be used for further analysis, allowing for a rigorous analysis of the factors that must be taken into account in the presence of the possible scenario of a new regulation for access to the public university system in Spain. Also it could be of interest to public universities when designing their advertising campaigns in order to attract the most talented students.

We cannot forget that this work was undertaken in the Spanish public university system, where there are general universities, but also specialized universities -for example, Technical Universities focused on Engineering and Architecture Degrees. Therefore, recruitment targets are significantly differentiated.

The result of this research, and their application to the model proposed in Hervás, Guàrdia, Peró, Capilla and Soriano (2013), will analyze future demand and efficiently manage recruiting actions.

Consequently, an AA analytical procedure would allow universities to customize their recruiting actions to attract new students based on their needs and/or interests. In this sense, Campbell et al. (2007) present the case of Baylor University as an example of "Enrolment Predictive Modeling" in a system completely different from the Spanish Public Universities System (SUPE)."

\section{CONCLUSIONS}

This paper presents a psychometric study of a questionnaire which aims to assess variables relating the aspects involved in the selection process and accessing the Spanish public university system. This questionnaire considers six factors: Consideration of the University; Perceived Usefulness; Social Impact; Vocational Aspects; Influence of Surroundings and Geographic Location. 
The statistical effect of the six factors set forth in the questionnaire, and some of the grouping variables that have been included require further analysis, because in some cases the data is very relevant depending on the new access mechanism defined, including data on factors such as whether students are willing to change geographic location or the degree of information required to make a better decision on which degree and university to choose.

Finally, it should be borne in mind that this study has certain limitations that should be considered when trying to generalize its results. Firstly, there is a certain asymmetry between the universities included in the sample, meaning that there might be groups which are under-represented, such as smaller and more recently created universities. Secondly, there is an obvious bias in the accidental non-probability sampling, since recruitment of students was voluntary and depended on factors not controlled by the authors. A broader sampling such as that being gathered for the 2012-2013 academic year should minimize this error.

Significant differences were found between the various evaluations criteria set out in the survey, dependent on whether the student chooses one area or another. Results also differed depending on gender. Therefore it is reasonable to assume that a large enough sample would allow us to discriminate the results by areas, and to determine the criteria prioritized by the students when making their choices.

If a Psychology student gives priority to different criteria than a Civil Engineering, Computer Science or Medicine student, when choosing a university and degree program, as suggested by the results of this study, recruiting must be approached differently and specifically aimed at the defined target audience in order to be most effective. We believe that knowledge of this information is strategic, especially for the management teams of the universities.

Our immediate objectives for further research will therefore focus on increasing the sample size, apply the results to the structural model proposed in this study, and then perform a comprehensive analysis of the results, taking into account aspects such as gender, study areas, and other possible typologies.

Finally, a question that follows after the students have got into a given University is whether there is any relationship between their performance and the access criteria (Shane et al, 2011; Capilla et al, 2008). This study would be part of the second phase of this work..

\section{REFERENCES}

Ariño, A., Hernández, M., Llopis, R., Navarro, P., \& Tejerina, B. (2008). El oficio de estudiar en la universidad: compromisos flexibles. Valencia: PUV.

Baker, S., \& Brown, B. (2007). Images of excellence: constructions of institutional prestige and reflections in the university choice process. British Journal of Sociology of Education, 28 (3), 377391.

Barnes, N. G., \& Mattson, E. (2009). Social media and college admissions: The first longitudinal study. Center for Marketing Research. Retrieved May, 5, 2009. https://www.umassd.edu/media/ umassdartmouth/cmr/studiesandresearch/socialmediaadmissions.pdf

Benson, V., Morgan, S., \& Filippaios, F. (2014). Social career management: Social media and employability skills gap. Computers in Human Behavior, 30, 519-525.

Bowden, J., \& Wood, L. (2011). Sex doesn't matter: the role of gender in the formation of studentuniversity relationships. Journal of Marketing for Higher Education, 21(2), 133-156. http://dx.doi.org/10.1080/08841241.2011.623731

Browne, M.W., \& Cudeck, R. (1992). Alternative ways of assessing model fit. Sociological Methods and Research, 21, 230-258.

Campbell, J.P., DeBlois, P.B., \& Oblinger, D.G. (2007). Academic Analytics: A New Tool for a New Era. EDUCAUSE Review, 42(4), 40-57.

Capilla, R. (2009). Análisis estratégico de los estudios TIC en la Universidad Politécnica de Valencia. Valencia: Universitat Politècnica de València. http://riunet.upv.es/handle/10251/5767 Retrieved 19/06/2013. 
Capilla Lladro, R., Hervas Jorge, A., Jimenez, P. P. S., \& Salt, J. A. (2012, June). Vocational training as a reservoir of students in the ICT sector. In Technologies Applied to Electronics Teaching (TAEE), 2012 (pp. 298-303). IEEE.

Cheung, C.M.K., Chiu, P-Y., \& Lee, M.K.O. (2011). Online social networks: why do students use facebook?. Computers in Human Behavior, 27, 1337-1343.

Corominas, A., \& Sacristan, V. (2011). Las encrucijadas estratégicas de la universidad pública española. Revista de Educación, 355, 57-81.

Dawson, S., Macfadyen, L., Lockyer, L., \& Mazzochi-Jones, D. (2011). Using social network metrics to assess the effectiveness of broad based admission practices. Australasian Journal of Educational Technology, 27(1), 16-27.

Ford, D.Y. (2008). The underrepresentation of minority students in gifted education: Problems and promises in recruitment and retention. The Journal of Special Education, 31(1), 4-14.

Gale, D., \& Shapley, L. S. (1962). College Admissions and the Stability of Marriage. The American Mathematical Monthly, 69(1), 9-15.

Goldstein, P. J. and R. N. Katz (2005). Academic analytics: The uses of management information and technology in higher education, Tech. Rep. December EDUCAUSE Center for Applied Research 8.

Gómez Aguilar, D. A., F. J. García-Peñalvo and R. Therón (2013). Evaluación visual de las relaciones entre participación de los estudiantes y sus resultados en entornos de e-learning. XV Simposio Internacional de Tecnologías de la Información y las Comunicaciones en la Educación Conjuntamente con el Congreso Español de Informática (CEDI 2013).

Gómez Aguilar, D. A., R. Therón and F. J. García-Peñalvo (2009). Semantic spiral timelines used as support for e-learning. Journal of Universal Computer Science (j-jucs) 15 (7): 1526-1545.

Long, P. and G. Siemens (2011). Penetrating the Fog: Analytics in Learning and Education. EDUCAUSE Review 46 (5)

Guàrdia. J., Peró, M., Hervás, A., Capilla, R., Soriano, P.P., \& Porras, M. (2012). Factores asociados con la decisión de cursar estudios universitarios de Psicología. Una aproximación mediante modelos de ecuaciones estructurales. Anuario de Psicología, 42(1), 87-104.

Guàrdia. J., Peró, M., Hervás, A., Capilla, R., Soriano, P.P., \& Porras, M. (2013). Factores asociados con la elección de titulación en el sistema universitario público español. Estudio de un modelo de ecuaciones estructurales. Technical report.http://riunet.upv.es/handle/10251/30128. Retrieved 26/06/2013.

Guerra, G., \& Rueda, E.M. (2005). Estudio longitudinal de los jóvenes en el tránsito de la enseñanza secundaria a la universidad: orientación, expectativas, toma de decisiones y acogida de los nuevos estudiantes en la universidad. http://www.uva.es/export/sites/default/portal/adjuntos/documentos/1145376143700_estudio_lon gitudinal_jovenes.pdf. Retrieved 19/06/2013.

Hervás, A., Guàrdia. J., Peró, M., Capilla, R., \& Soriano, P.P. (2013). A structural equation model for analysis of factors associated with the choice of engineering degrees in a Technical University. Abstract and Applied Analysis. Article ID 368529, 7 pages, http://dx.doi.org/10.1155/2013/368529

Hu, L., \& Bentler, P.M. (1999). Cutoff criteria for fit indexes in covariance structure analysis: Conventional criteria versus new alternatives. Structural Equation Modeling, 6, 1-55.

Huffman, A. H., Whetten, J., \& Huffman, W. H. (2013). Using technology in higher education: The influence of gender roles on technology self-efficacy. Computers in Human Behavior, 29(4), 1779-1786.

Leppel, K., Williams, M.L., \& Waldauer, C. (2001). The Impact of Parental Occupation and Socioeconomic Status on Choice of College Major. Journal of Family and Economic Issues, 22 (4), 373-394.

León, G. (2011). Nuevos enfoques para la gestión estratégica de I+ D e innovación en las universidades. Revista de Educación, 355, 83-108. 
Lubben, F., Davidowitz, B., Buffler, A., Allie, S., \& Scott, I. (2010). Factors influencing access students' persistence in an undergraduate science programme: a South African case study. International Journal of Educational Development, 30(4), 351-358. doi: 10.1016/j.ijedudev.2009.11.009.

Llera, F.J. (2010). UPO Barómetro. Estudio de Opinión. Sevilla: Universidad Pablo Olavide.

Maringe, F. (2006). University and course choice Implications for positioning, recruitment and marketing. International Journal of Educational Management, 20 (6), 466-479.

Misran, N., Sahuri, S. N. S., Arsad, N., Hussain, H., Zaki, W. M. D. W., \& Aziz, N. A. (2012). The influence of socio-economic status among matriculation students in selecting university and undergraduate program. Procedia-Social and Behavioral Sciences, 56, 134-140.

Minaei-Bidgoli, B., Kashy, D. A., Kortmeyer, G., \& Punch, W. F. (2003, November). Predicting student performance: an application of data mining methods with an educational web-based system. In Frontiers in Education, 2003. FIE 2003 33rd Annual (Vol. 1, pp. T2A-13). IEEE.

Murphy, P.E., \& McGarrity, R.A. (1978). Marketing Universities: A Survey of Student Recruitment Activities. College and University, 53 (3), 249-61.

Muñiz, J. (2005). Utilización de los test. En J. Muñiz, A.M. Fidalgo, E. García-Cueto, R. Martínez y R. Moreno (Eds.). Análisis de los ítems, (pp. 133-172). Madrid: La Muralla, S.A.

Parry, J., Mathers, J., Stevens, A., Parsons, A., Lilford, R., Spurgeon, P., \& Thomas, H. (2006). Admissions processes for five year medical courses at English schools: review. British Medical Journal, 332 (7548), 1005-9.

Perna, L.W., \& Titus, M.A. (2004). Understanding Differences in the Choice of College Attended: The Role of State Public Policies. The Review of Higher Education, 27 (4), 501-525.

Price, I., Matzdorf, F., Smith, L., \& Agahi, H. (2003). The impact of facilities on student choice of university. Facilities, 21 (10), 212-222.

Romero, C., \& Ventura, S. (2007). Educational data mining: A survey from 1995 to 2005. Expert Systems with Applications, 33(1), 135-146.

Sukegawa, N., \& Yamamoto, Y. (2012). Preference profiles determining the proposals in the GaleShapley algorithm for stable matching problems. Japan Journal of Industrial and Applied Mathematics, 29(3), 547-560. Doi: 10.1007/s13160-012-0077-x.

Tinto, V. 2006. Research and practice of student retention: what next? Journal of College Student Retention: Research, Theory and Practice, vol. 8, no 1, p. 1-19.

Turner, C.S.V., \& Thompson, J.R. (1993). Socializing Women Doctoral Students: Minority and Majority Experiences. Review of Higher Education, 6, 232-241.

Yurtseven, T. (2002) How does the image of engineering affect student recruitment and retention? A perspective from the USA. New York: Global Journal of Engineering Education. 6(1), 17-23. 


\section{Appendix A: Questionnaire}

(Original in Spanish. Note that this is the translation of a questionnaire on the Spanish public university system, which must be adapted for use in other countries or university systems)

This is a brief survey prepared by a group of researchers from different Spanish universities, aimed at evaluating some aspects related to University access by new students.

Please answer the following questions honestly without leaving any items blank. This questionnaire will only take you a few minutes

All information gathered is solely for research purposes and will be treated statistically, without dissemination of your specific data or answers:

Degree:

Sex $\quad \square$ Female $\quad \square$ Male

WHAT WAS YOUR ACCESS MARK?

WHAT BACCALAUREATE AREA WERE YOU IN?

$\square$ Arts $\quad \square$ Social Sciences $\quad \square$ Scientific-Technical $\quad \square$ Health $\square$ Humanities

THIS DEGREE WAS MY FIRST CHOICE WHEN PRE-REGISTERING:

$\square$ YES $\square$ NO

THIS UNIVERSITY WAS MY FIRST WHEN PRE-REGISTERING

$\square$ YES $\square$ NO

WHAT YEAR DID YOU ENROLL IN THIS DEGREE COURSE?

THE CUT-OFF MARK HAS INFLUENCED MY CHOICE (CHECK ONLY ONE OF THE FOLLOWING OPTIONS):

\begin{tabular}{|c|c|c|c|c|c|c|c|}
\hline $\begin{array}{c}\text { Totally } \\
\text { disagree } \\
1\end{array}$ & 2 & 3 & $\begin{array}{c}\text { Partially } \\
\text { agree } \\
4\end{array}$ & 5 & 6 & $\begin{array}{c}\text { Totally } \\
\text { agree } \\
7\end{array}$ & $\begin{array}{c}\text { No } \\
\text { answer. }\end{array}$ \\
\hline & & & & & & & \\
\hline
\end{tabular}

DID YOU KNOW HOW MANY PLACES WERE BEING OFFERED?

$\square$ YES $\square$ NO

IN VIEW OF MY ACCESS MARK, I COULD CHOOSE THE DEGREE I PREFERRED.

$\square$ YES $\square$ NO

Mark only one option for each statement

\begin{tabular}{|c|c|c|c|c|c|c|c|c|}
\hline Number & ITEM & 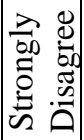 & & & & & & 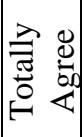 \\
\hline & & 1 & 2 & 3 & 4 & 5 & 6 & 7 \\
\hline 1 & I chose from degrees in which I knew I could be admitted & & & & & & & \\
\hline 2 & How near the university is to my home was a decisive factor & & & & & & & \\
\hline 3 & I would prefer to study in another place (city, region, etc.) & & & & & & & \\
\hline 4 & My colleagues influenced my decision & & & & & & & \\
\hline 5 & The counselor helped me to take a decision & & & & & & & \\
\hline
\end{tabular}




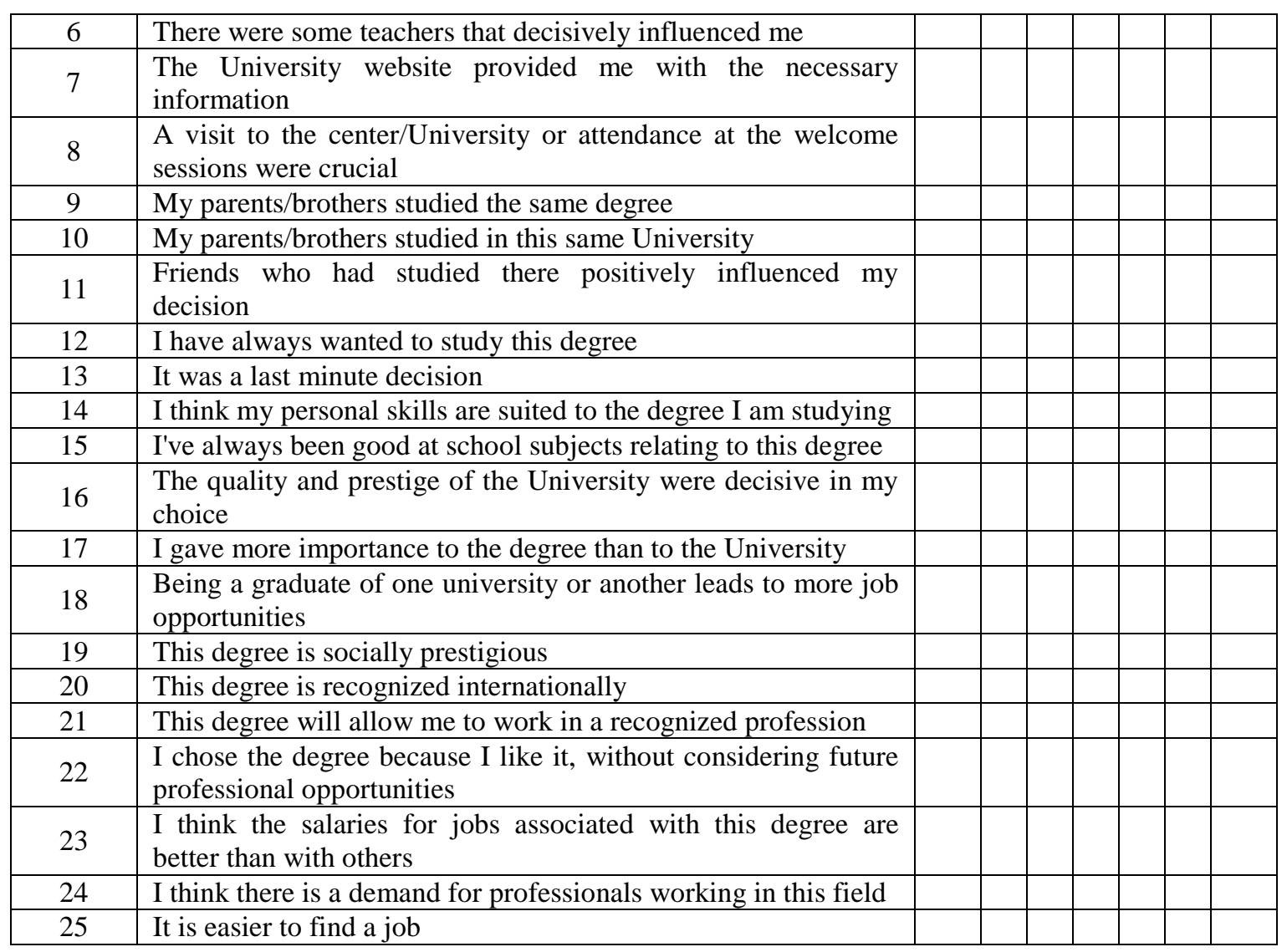

